\title{
Fish Consumption Habits of Teachers
}

\author{
Şennan YÜCEL*, Birol BAKI** \\ "Sinop University, Faculty of Fisheries, Department of Fisheries Basic Science, Sinop, \\ ${ }^{* *}$ Sinop University, Faculty of Fisheries, Department of Aquaculture, Sinop,
}

\begin{abstract}
In this study, it was aimed to determine the fish consumption preferences and consumption habits of teachers in the Central Black Sea (Sinop and Samsun) region.

The study was conducted in Samsun and Sinop provinces between June-July 2000 and April-May 2016. The data obtained by the survey from 502 teachers in total working in the city centres constituted the primary data of the study. The data obtained from the Ministry of National Education and the Ministry of Food, Agriculture and Livestock, General Directorate of Fisheries and Aquaculture constituted the secondary data of the study. In the study, it was determined that almost all of the teachers preferred to consume fresh fish, more than half of them preferred to consume it by cooking on the grill. Considering the frequency of fish consumption, $39 \%$ consume it at least once a week and $28 \%$ consume it at least once every two weeks in 2016 ( $>>0.05)$.

There were no differences between the provinces in terms of meat preferences $(p<0.05)$.

Turkey has a significant potential in terms of the production of fishery products. Much lower fish consumption than the world average is as surprising as significant. For a healthy society, using all kinds of means of communication, the improvement of fish consumption habits should be gained and priority must be given to increase the consumption of fish meat. For this reason, fish consumption habits of the teachers in the same education and income group were determined by considering the effect of different geographical regions and different income groups on different dietary habits in the study.
\end{abstract}

Keywords: Fish meat consumption, the Central Black Sea, Consumption Habits, survey

\section{INTRODUCTION}

The increasing world population in recent years causes protein resources of animal origin to be inadequate and fishery products that gain more importance with each passing day and have an important place in nutrition in terms of animal protein are the leading among the resources to be benefited from in meeting the protein deficit in the best and cheapest way [1].

When the geographical location, ruralurban migration, urbanisation and demographic structure of Turkey are examined together, it is a fact that animal protein needs have an important place in nutrition. Aquaculture is considered to be an alternative in the consumption of animal protein.

When the production between the years of 2000-2015 is examined, it is observed that while a total production amount follows an up and down course depending on the fishing production, the consumption amount per capita shows a similar trend to the total production amount depending on the years. The consumption amount per capita decreased from $8,1 \mathrm{~kg} /$ year to $6,2 \mathrm{~kg} /$ year in the last decade [2].

A strong social perception of the fact that adequate and balanced nutrition has an important place in maintaining a healthy and quality life has been formed. This perception is also supported by the results of numerous scientific studies. Adequate and balanced nutrition is closely related to dietary habits. Issues such as access to nutrients, income status, socio-economic status of the societies, age and educational status have an impact on the shaping of dietary habits. On the other hand, it is inevitable that adequate and balanced nutrition is considered as a factor together with education and health indicators and is regarded as an indicator of the level of development [3].

It is stated that a human should consume 70 gr of protein per day for adequate and balanced nutrition and $47 \mathrm{gr}$ of it should be of animal origin [4]. There are many studies on fish consumption conducted on different subjects in different regions $[5] ;[6] ;[7] ;[8] ;[9] ;[10] ;[11] ;[12] ;[13] ;[14] ;[15] ;[16]$ ;[17];[18].

In this study, it was aimed to determine the fish consumption preferences and consumption habits of teachers in the Central Black Sea (Sinop and Samsun) region during the 2000-2016 year.

\section{MATERIAL AND METHOD}

The study was conducted in Samsun and Sinop provinces between June-July 2000 and AprilMay 2016. The data obtained by the survey from 502 teachers in total working in the city centres constituted the primary data of the study. The data 
obtained from the Ministry of National Education and the Ministry of Food, Agriculture and Livestock, General Directorate of Fisheries and Aquaculture constituted the secondary data of the study.

Due to the nature of the study, a nonreturnable selection was made since the interviews would be held only once with each subject. The following formula was used to determine the number of the subjects to which a survey would be applied.

$$
n=\frac{N p q t_{\alpha}^{2}}{(N-1) d^{2}+p q t_{\alpha}^{2}}
$$

$[\mathrm{N}=$ Total number of units; $\mathrm{n}=$ Sample diameter; $\mathrm{p}=$ Positive probability; $\mathrm{p}=$ Negative probability; $\mathrm{d}=$ margin of error (e.g. $5 \%) ; \mathrm{t}_{\mathrm{a}}=$ table value (e.g.1,96)] [19];[20].

The sample diameter was determined by taking the fish consumption probability as $\mathrm{p}=0.80$ [21] and the margin of error as $d=0,05$. Face to face interviews were performed with the teachers. The subjects were asked 23 questions in the survey.

The preliminary units of the population that form the study are gathered in the $\mathrm{X}_{\mathrm{A}}$ and $\mathrm{X}_{\mathrm{B}}$ levels. There are $\mathrm{k}$ units in $\mathrm{X}_{\mathrm{A}}$ and $\mathrm{m}$ preliminary units in $\mathrm{X}_{\mathrm{B}}$.

Using the principles of the Simple Cluster Sampling technique, the districts were determined at the first level $\left(\mathrm{k}_{\mathrm{i}}\right)$ and the schools in these settlements $\left(\mathrm{m}_{\mathrm{j}}\right)$ were determined at the second level by the simple random sampling technique by considering each district as a cluster.

$$
X_{A}=\sum_{i=1}^{k} k_{i} \quad X_{B}=\sum_{j=1}^{m} m_{j}
$$
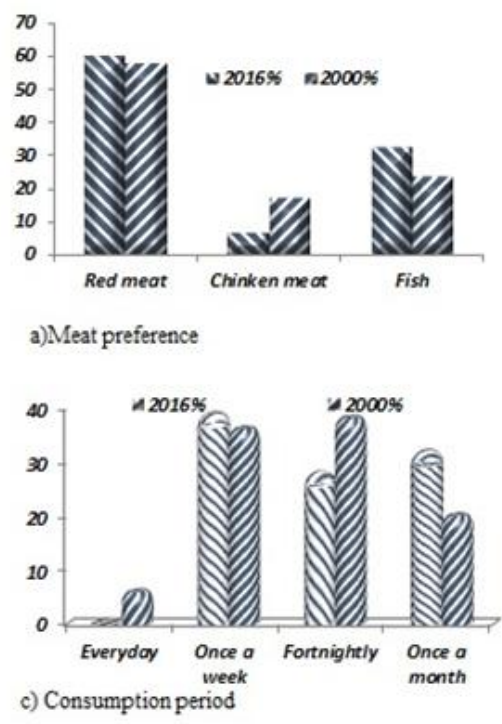

Considering the number of teachers at schools, final clusters

$$
n=n_{1}+n_{2}+n_{3}+\ldots+n_{m} \quad \mathrm{n}=\sum_{\mathrm{i}=1}^{\mathrm{m}} \mathrm{n}_{\mathrm{i}}
$$

were formed by random sampling according to the sample size.

Microsoft Excel 2013 program was used for the descriptive statistics of the data obtained from the study and SPSS 21 and MINITAB 16 statistical software packages were used for the statistical analysis by using the Chi-Square Analysis, and Kruskal-Wallis tests.

\section{RESULTS}

$10 \%$ of the subjects in the study in 2000 were single and $18 \%$ of them were single in 2016 and females constituted one-third of the subjects. Most of the subjects prefer fishery products (Sinop $100 \%$, Samsun 95\%).

While $93 \%$ of the subjects wanted fish selling areas to be located in one place in 2000, this rate became $80 \%$ in 2016 ( $\mathrm{p}<0.05)$. Furthermore, while the rate of those who found fish selling areas sufficient in 2000 was $7 \%$, it increased to $17 \%$ in 2016.

$39 \%$ of the subjects in Sinop and 28\% of the subjects in Samsun stated that the fish was the most delicious meat $(\mathrm{p}<0,05)$. Upon examining the data for the years of 2000 and 2016, it was observed that the red meat preference was near $60 \%$ and that in 2016, there was an increase of $9 \%$ in those considering the fish as the most delicious meat (Fig. $1 / a)$.
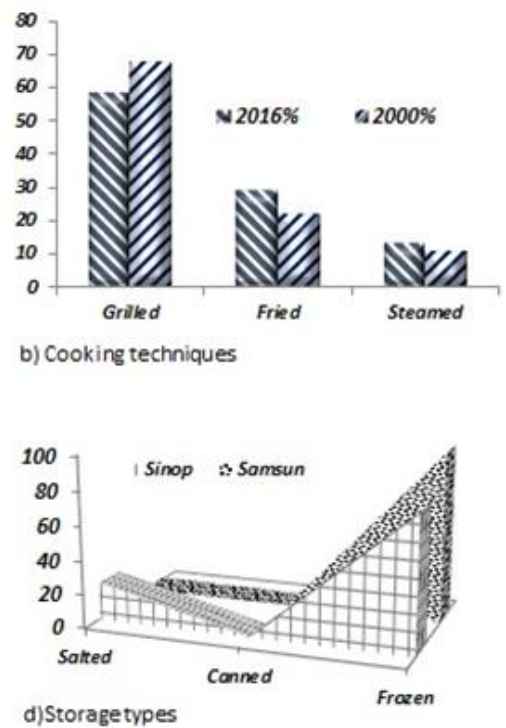

Figure 1. Meat Consumption Preferences 
In the study, upon examining the cooking techniques of fish meat, it was determined that $67 \%$ preferred grilled, $22 \%$ preferred fried, and $11 \%$ preferred steamed fish in 2000, while 58\% preferred grilled, 29\% preferred fried, and 13\% preferred steamed fish in $2016(\mathrm{p}<0.05)$ (Fig. 1/b).

While the rate of the teachers who declared that they consumed fish every day in 2000 was $6 \%$, the rate of those consuming fish at least once a week was $36 \%$ and the rate of those consuming fish at least once every two weeks was $38 \%$. The frequency of fish consumption was determined to be $39 \%$ at least once a week and to be $28 \%$ at least once every two weeks in 2016 (p>0,05) (Fig. 1/c).

In the study, in addition to the consumption of fresh fish, it was determined that the products were stored to be consumed later by using different preservation methods $(25 \%)$. While there was no difference $(\mathrm{p}<0.05)$ between the years in terms of fish storage amounts, it was determined that there was a difference between the study areas (Sinop, Samsun) $(\mathrm{p}<0.05)$. While the rate of those who use especially fish meat salinization technique is $2 \%$ in Samsun and $22 \%$ in Sinop, it is thought that this situation originates from the historical background of the provinces (Fig. 1/d).

\section{DISCUSSION}

The geography of Turkey spreads over a wide area and different climate zones are experienced simultaneously. These and similar differences provide societies with the access to different fresh products at the same time. For these reasons, societies acquire different consumption habits in different regions.

In the study, consumption habits of the teachers in the same education and income group were determined to minimise dietary habits in different geographical regions and of different income groups.

It was determined that the fish consumption showed an increase in recent years although approximately $60 \%$ of the subjects in the study preferred meat. Similar evaluations were made in other studies conducted ([11];[12];[15]). Most of those who preferred fish meat stated to consume it freshly. Similar results were expressed in the studies conducted in different regions ([9];[16];[17]).

In terms of the frequency of consumption, a large majority $(74 \%)$ of the subjects prefer fish once a week or once every two weeks. In other studies conducted, it was stated that the ratio of those who consumed fish at least twice a month in [7] Izmir central districts and once a week in [22] Çanakkale was $43-46 \%$, the ratio of those who consumed fish once a week in [23] Elazığ province was $25 \%$ and once every two weeks was $28 \%$. Although fish consumption once in a week or 15 days increased by about $10 \%$ in the last 15 years in the study, it is not possible to say that this is enough. It is an expected result that the fish consumption is more intense when it is considered that it is easy to access fresh fish in the area where the study is conducted and most of the subjects like fish. Furthermore, it can be said that the consumption values in the region are above the average of the fish consumption per capita in Turkey.

In the study, it was determined that a large majority of the subjects preferred saltwater fish (Sinop 100\%, Samsun 95\%). It was reported that [17] although it does not have coasts, saltwater fish is preferred at 85.4\% in Ankara and it was preferred in Elazı $\breve{g}$ [23] despite the high trout breeding production and carp hunting.

The fact that the fish selling area availability rate increased from $7 \%$ in 2000 to $17 \%$ in 2016 is a result of positive developments in audits, along with the increase in the consumer awareness. Although there have been significant changes in food selling areas in Turkey in recent years, in order to increase the satisfaction of consumers with the current situation of fish selling areas, in addition to the physical infrastructure, legal obligations must be fulfilled. These regulations will positively affect the total consumer satisfaction, considering the fact that [22] there is no relationship between the fish selling area preference and the income level. Considering that there is a linear relationship between the income level and consumption ([24]; [5]), it is thought-provoking that the fish consumption preferences of the teachers with the same education and income levels decreased from 58\% in 2000 to $33 \%$ in 2016. Although Turkey has a significant potential in terms of fish consumption, necessary measures should be taken to increase the purchasing power, which can be characterised as one of the obstacles to bringing the level of the fish consumption per capita to that of the developed countries.

The fact that non-fresh fish is a food which is quickly spoilt and emits an odour and the opinion in the society that not fresh fish can poison adversely affect the consumption. In order to eliminate these negativities, it is necessary to preserve the cold chain, increase the product shelf life by using various processing technologies and prepare action plans suitable for the regional conditions. For a healthy society, it is necessary to get the society adopt a fish consumption habit and to increase fish consumption in all segments of the society as a priority by using all kinds of communication means. 


\section{REFERENCES}

[1]. M Aydin, M. and Karadurmus, U. 2012. Consumer Behaviours for Seafood in Ordu Province. Yunus Araștırma Bülteni, 2012 (3):18-23.

[2]. TUIK, 2016. Seafood Statistics for 2015. tuikapp. tuik. gov.tr/ medas/ ?kn=97 \&locale $=$ tr $\quad$ date accessed, 03.06.2016).

[3]. Yağmur, C. and E. Güneş, 2010. Examination of the food production and consumption in Turkey in terms of balanced nutrition, VII. Ziraat Mühendisliği Teknik Kongresi, Ankara.

[4]. Seçer,S., Rad,F.,1993. Seafood and Nutrition Policy, Su Ürünleri Sетровуити. TMМOB Ziraat Mühendisleri Odas1. 12-13 Ekim, Ankara.

[5]. Hatırlı, S.A., Demircan, V. and Aktaş, A.R. 2004. The Analysis of the Fish Consumption of Families in Isparta Province, Süleyman Demirel Üniversitesi İktisadi ve İdari Bilimler Fakültesi, 2004, C.9, S.1 s.245-256.

[6]. Gürgün, H., 2006. An Investigation Info the Fish Concumption in Some Towns On the Shores of Lake Van. Ç.Ü. The Department of Aqua Products Hunting and Process Technology

[7]. Sayg1, H; Saka, Ş; Fırat, K and Katağan, T.; 2006. Approach of the Public in Izmir Central Districts to Fish Consumption and Fish Breeding, E. $\ddot{U}$. Su Ürünleri Dergisi, Cilt 23, Say1 (12): 133-138, İzmir.

[8]. Cevger Y, Yalçın C and Aral Y (2005): Food safety and stockbreeding policies in animal production in Turkey, 272284. Gıda Güvenliği ve Güvenirliği Seтроzуити, 20-22 Ekim 2005, Biyologlar Derneği, Tam Metinler Kitabı, Ankara.

[9]. Adıgüzel, F., Civelek, O., Sayılı, M. and Büyükbay, E.O. 2009. Fish Consumption Situation of the Families in Almus District of Tokat Province, GOÜ Ziraat Fakültesi Dergisi, 26 (2):35-43.

[10]. Şanlıer, N.; Konaklıoğlu, E. and Güçer, E.; 2009. The Relationship Between the Nutrition Knowledge,
Habits and Behaviors of the Youth and

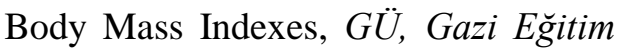
Fakültesi Dergisi, Cilt 29, Sayl 2 (2009) 333-352, Ankara.

[11]. Tosun, Ö.O. and Hatırl1, S.A. 2009. Anaylsis of the Consumers' Red Meat Purchase Area Preferences: The Case of Antalya Province, Süleyman Demirel Üniversitesi İktisadi ve İdari Bilimler Fakültesi Dergisi. C.14,S.2,s.433-445. Isparta.

[12]. Yaylak, E., Taşkın, T., Koyubende, N.,Konca,Y., 2010. A Study on the Determination of Red Meat Consumption Behaviors in Ödemiş District of Izmir Province, Hayvansal Üretim 51(1): 21-30.İzmir.

[13]. Uzundumlu, A. S., Şık H. B. And Kirl1 H.; 2011. Analysis of the Factors Affecting the Consumption of Red and White Meat Consumption in Küçükçekmece District of Istanbul Province, Atatürk Üniversitesi, Ziraat Fakültesi, Tarım Ekonomisi Bölümü, Erzurum.

[14]. Şeker, İ., Özen, A., Güler, H., Şeker, P. and Özden, İ., 2013. Red Meat Consumption Habits in Elazı $\breve{g}$ and Opinions of Consumers on Animal Welfare, Kafkas Univ Vet Fak Dergisi 17 (4): 543-550,

[15]. Lorcu, F. and Bolat, B.A., 2012. The Examination of Red Meat Consumption in Edirne Province, Tekirda $\breve{g} \quad$ Ziraat Fakültesi Dergisi.Cilt:1 9, Sayı:1,s.71-85. Tekirdağ.

[16]. Aydın, M. and Karadurmuş, U., 2013. Seafood Consumption Habits in Trabzon and Giresun Regions, Karadeniz Fen Bilimleri Dergisi 3(9):57-71, Giresun.

[17]. Yavuz G.G.; Ataseven, Z.Y.; Gül, U.and Gülaç, Z. N.; 2015. Factors Affecting Consumer Preferences in Seafood Consumption: The Case of Ankara Province, Türkiye. Yunus Araştırma Bülteni 2015 (1): 73-82, Trabzon.

[18]. Türkmen, M., Türkmen, A. and Duran, K., 2016. The Investigation of Fish Consumption in Giresun Province, 
Türk Tarım - Gıda Bilim ve Teknoloji

Dergisi, 4(8): 712-718, 2016.

[19]. Çiçek,A. and Erkan,O., 1996. Research and Sampling Methods in Agricultural Economics, GOPÜ., Ziraat Fakültesi Yayınları No.:12 Ders Kitapları Serisi No:6, Tokat.

[20]. Baş, T., 2008. Anket. Araştırma Yöntemleri Dizisi:2, Seçkin Yayıncılık, 5.Bask1, Ankara.

[21]. Elbek, A. G., Emiroğlu İşgören, D. and Sayg1, H. 1999. Seafood Consumption in Izmir Province, Ege Üniversitesi Su Ürünleri Fakültesi Yayınları, No:57, Bornova, İzmir, 36s.

[22]. Çolakoğlu, F,A., İşmen, A., Özen, Ö., Çakır, F., Yı̆̆ın, Ç. and Ormancı, H.B.,2006. The Evaluation of Seafood Consumption Behaviours in Çanakkale Province, E.Ü. Su Ürünleri Dergisi, Cilt 23, Ek. (1/3): 387-392 . İzmir.

[23]. Çiçek, E., Akgün,H. and İlhan, S., 2013. The Determination of Fish Meat Consumption Habit and Preference in Elazığ Province, Yunus Araştırma Bülteni 2014 (1): 3-11.

[24]. Baysal A., 2003. The effect of social inequality on nutiriton, CÜ Tip Fak Derg, 25,66-72. 